\title{
CARBON STORAGE RESPONSES OF SUBALPINE FORESTS TO MOUNTAIN PINE BEETLE OUTBREAKS UNDER CURRENT AND ALTERED CLIMATE REGIMES IN WESTERN NORTH AMERICA
}

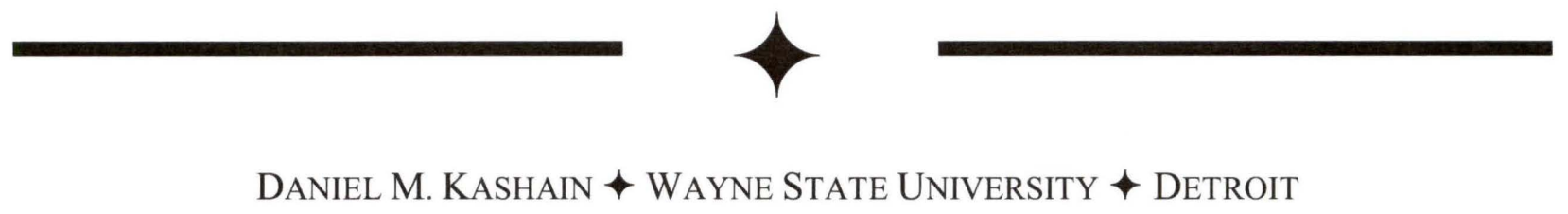

\begin{abstract}
$\downarrow$ AbSTRACT
Understanding how climate, disturbances, and carbon storage interact in subalpine forests is critical for assessing the role of this ecosystem in the global carbon budget under altered climate scenarios. Most research to date in western North American forests has focused on wildfire effects on carbon storage and net ecosystem productivity (NEP). The current extensive insect outbreak in this region, however, suggests that insects such as the mountain pine beetle (MPB) are an important driver of carbon dynamics and may determine whether western landscapes are carbon sinks or sources. The overall objective of this study is therefore to understand how MPB outbreaks affect forest carbon storage at stand and landscape scales under multiple climate scenarios. Specific objective include examining how carbon storage changes with stand development following beetle outbreaks, how variability in outbreak extent, frequency, and post-outbreak stand development affect landscape-scale carbon storage, and how beetle outbreaks and climate interact. This research will, for the first time, provide data documenting post-outbreak carbon dynamics under current and altered climate scenarios. These data will provide the basis for developing a carbon-based, ecological rationale for future outbreak management in western forests.
\end{abstract}

\section{$\downarrow$ INTRODUCTION}

Subalpine forests in western North America sequester and store significant amounts of carbon (C) whose storage and release is regulated by disturbances correlated to climate (Kashian et al. 2006). Insect outbreaks are second only to wildfires as the largest source of tree mortality in western North America (Samman and Logan 2000); about $40 \%$ of lodgepole pine forests in the western U.S. are currently susceptible to MPB attack (Hicke and Jenkins, submitted). Mortality associated with outbreaks clearly affects forest structure, particularly tree regeneration and canopy cover and live and dead biomass, as well as processes including productivity (Romme et al. 1986) and stand recovery (Fleming et al. 2002). These changes may significantly influence forest $\mathrm{C}$ balances in ways very different than fires (Kurz and Apps 1999), but understanding how $\mathrm{C}$ storage in western forests responds to MPB outbreaks under current and altered climates represents a substantial knowledge gap.

Climate is a major driver of insect outbreaks in western North America (Carroll et al. 2004; Fastie et al. 1995; Logan and Powell 2001). Projected climate change may influence the extent, severity, or frequency of future outbreaks (Fleming 2000; Hicke et al. in press; Logan et al. 2003; Williams and Liebhold 2002), potentially affecting whether a regional forest gains or loses C to the atmosphere (Kurz and Apps 1999). Currently, a series of mountain pine beetle (MPB) outbreaks unprecedented in extent are affecting nearly 10 million ha of forests in the western United States and Canada (USDA Forest Service 2005). Despite their potential implications for $\mathrm{C}$ storage, the impacts of insect outbreaks on forest productivity and $\mathrm{C}$ cycling are poorly quantified and poorly understood. This lack of baseline data represents an important problem because it prevents meaningful predictions of the rate 
and direction of post-outbreak changes in $\mathrm{C}$ cycling in forests under the current climate. These predictions are critical for assessing future inputs of carbon to the atmosphere via natural disturbances under altered climate scenarios.

The proposed research will provide currently missing data describing the potential for western North American forests to be converted from $\mathrm{C}$ sinks to $\mathrm{C}$ sources following MPB outbreaks. This contribution is significant because it will provide the basis for understanding outbreak influences on forest ecosystem processes and for modeling future $\mathrm{C}$ dynamics in the context of continued environmental stresses on forests, including climate change. The overall objective of this research is to understand how MPB outbreaks affect forest $\mathrm{C}$ storage at landscape scales under multiple climate scenarios. The central hypothesis of this work is that by reducing net primary production and increasing decomposition at stand and landscape sales, MPB outbreaks will cause forests to act as a short-lived C source to the atmosphere before returning to a $\mathrm{C}$ sink weakened by the outbreak. Furthermore, climate change leading to larger, more frequent, or more severe outbreaks will exacerbate this trend. I am testing this central hypothesis by addressing the following three specific questions:

1. How does carbon storage vary with forest stand development following a beetle outbreak?

The working hypothesis for this objective is that an outbreak creates a short-lived $\mathrm{C}$ source to the atmosphere followed by a weaker but long-lived C sink as stands recover because it reduces stand net primary production and increases decomposition.

2. How do beetle outbreak extent, frequency, and postoutbreak stand development patterns interact to influence $\mathrm{C}$ storage at landscape scales?

I am hypothesizing that the landscape will act as a short-lived $\mathrm{C}$ source following an outbreak before returning to a $\mathrm{C}$ sink, but that the $\mathrm{C}$ stored and sequestered on the landscape as a sink will be substantially reduced.

3. What is the potential for climate change over the next 50-100 years to strengthen the feedback between beetle outbreaks and climate?

My working hypothesis is that climate change will reduce $\mathrm{C}$ storage on forested landscapes because it will increase severity, extent, and/or frequency of outbreaks, and that changes in forest structure following outbreaks will affect future outbreak events.
This work will build upon an existing, extensive data set that describes changes in $\mathrm{C}$ cycling following wildfire along replicated, long-term chronosequences (Kashian et al. in preparation). Using this approach, Question \#1 will provide empirical-based modeling of stand development and $\mathrm{C}$ storage following MPB outbreaks, and the quantification of the effects of MPB-induced tree mortality on C storage and loss. Question \#2 will use stand measurements to quantify landscape-level changes in C storage following MPB outbreaks and will provide the basis for understanding the implications of climate-induced changes in MPB outbreaks for $\mathrm{C}$ dynamics. Question \#3 will predict the effects of potential climate change scenarios on MPB outbreaks and associated $\mathrm{C}$ storage in subalpine forests over the next 50 to 100 years. The work will be applicable at local and regional scales because it will provide information to managers about the natural variability in insect-related disturbances across landscapes; this information is applicable to most subalpine landscapes in the Rocky Mountains. At national scales, the research will increase our understanding of landscape carbon storage following broad-scale disturbances (in this case insect outbreaks), which is important knowledge that may contribute to the formulation and revision of policies affecting the global carbon cycle and climate change.

\section{$\downarrow$ MeTHODS}

In the field, four separate chronosequences were identified based on their age when attacked and percent mortality of overstory trees due to beetle kill, each including a control and four time-since-attack classes (undamaged, 1-2 years, 3-5 years, 15-25 years, and 25-35 years) for a total of 72 stands. Because Yellowstone National Park has experienced relatively little beetle mortality, most stands in the first two age classes (12 years and 3-5 years since attack) were located in the Bridger-Teton National Forest, with a few in Grand Teton National Park. A majority of stands in the two oldest age classes were located within Yellowstone National Park. Stands were used to quantify all forest carbon pools (above- and belowground vegetation, snags, coarse woody debris, forest floor, and soil).

Stands were readily accessible by road or trail (i.e., within 1 kilometer of a road or trail). Each stand (cluster) includes three $10 \times 50 \mathrm{~m}$ plots, spaced 20-50 meters apart depending on the size of the polygon, with plots located at equal distances along a baseline. Each plot includes two belt transects along each of its long- 
axis borders. Belt transects were used to measure standing live and dead trees, stumps, and saplings, with transect width differing for overstory trees and saplings based on density. The center line of each belt transect was also used to select trees and saplings for allometric measurement and to select locations for sampling soil and forest floor. Twenty-five randomly selected saplings in each plot were measured at the base (total $=$ 75 per cluster). Ten mature trees were randomly selected for further sampling in each plot along the center line of each plot. For each tree, an increment core was extracted at breast height and the sapwood marked on the core, and tree height, height to crown base, and crown depth was measured. Finally, three dominant (oldest) live overstory trees were selected in each plot and an increment core extracted at the base for age determination.

Coarse woody debris was measured using eight 50 -foot transects run due east from each plot; CWD was tallied in five size classes, and classified for decay for the largest size class. For sampling forest floor and soil, five forest floor samples approximately $900 \mathrm{~cm}^{2}$ in area were collected along the center line of each plot; all forest floor material was collected to the top of the mineral soil and composited by plot. Composite samples were weighed in the field, and then subsampled. A soil core was extracted to $30 \mathrm{~cm}$ from the top of the mineral soil within the area the forest floor was collected and separated into a $0-15 \mathrm{~cm}$ sample and a $15-30 \mathrm{~cm}$ sample. Nine litter traps were deployed per stand to estimate annual litterfall, deployed 3 per subplot. Litter traps will be collected in July 2009 and 2010.

Soils and forest floor samples and increment cores were transported to the laboratory under refrigeration. For each soil sample, fine roots were separated from soil, classified into live and dead roots, and weighed. A subsample of soil was then taken, rocks and non-root organic matter removed, and weighed, dried, and weighed again to determine bulk density. Live and dead roots were ground in a Wiley mill and analyzed for percent carbon. Soils samples were ground on a roller mill and also analyzed for percent carbon. Forest floor litter subsamples were weighed, dried to constant mass, and weighed again. Excess soil will be sorted from litter samples, and the litter will be ground in a Wiley mill, subsampled again, and analyzed for percent carbon.

Increment cores were mounted and sanded per standard techniques. Tree ages will be determined from each increment core, and the average 10 -year ring width will be determined for each core using a sliding bench micrometer.

\section{PreliminARY Results \& PROGRess}

Five crew members were hired for the summer of 2008, and a total of 48 stands were located in the field (Table 1). In each stand, litter traps were deployed and plots were set out and flagged for relocation during the next field season. A potential trouble spot with this design is the difficulty in predicting the mortality (outbreak severity) in a stand currently being attacked; thus most stands in the 1-3 year and 3-5 year classes will need to be monitored closely during 2009 to account for any changes in mortality class that might occur, and many of the stands in these classes still need to be sampled in 2009. A total of 48 plots were sampled during the 2008 field season. All have been completely sampled, including all vegetation, soil, and forest floor samples. The remaining 24 stands in the 72 -stand study design will be located on adjacent National Forests in 2009.

\begin{tabular}{|c|c|c|c|c|}
\hline & \multicolumn{2}{|c|}{$30-50 \%$ Mortality } & \multicolumn{2}{|c|}{$>50 \%$ Mortality } \\
\hline & $150-200$ years & $>200$ years & $150-200$ years & $>200$ years \\
\hline Undamaged & \multicolumn{2}{|c|}{ All stands in this cell have been sampled } & \multicolumn{2}{|c|}{ All stands in this cell have been sampled } \\
\hline 1-2 years & $\begin{array}{c}\text { Three stands in this cell } \\
\text { have been sampled } \\
(1 \text { left })\end{array}$ & $\begin{array}{c}\text { Two stands in this cell have } \\
\text { been sampled } \\
\text { ( } 2 \text { left) }\end{array}$ & $\begin{array}{c}\text { Zero stands in this cell have } \\
\text { been sampled } \\
(4 \text { left })\end{array}$ & $\begin{array}{c}\text { Zero stands in this cell have } \\
\text { been sampled } \\
\text { ( } 4 \text { left) }\end{array}$ \\
\hline 3-5 years & $\begin{array}{c}\text { Three stands in this cell } \\
\text { have been sampled } \\
(1 \mathrm{left})\end{array}$ & $\begin{array}{c}\text { Zero stands in this cell have } \\
\text { been sampled } \\
\text { (4 left) }\end{array}$ & $\begin{array}{c}\text { Zero stands in this cell have } \\
\text { been sampled } \\
(4 \text { left })\end{array}$ & $\begin{array}{c}\text { Zero stands in this cell have } \\
\text { been sampled } \\
\text { ( } 4 \text { left })\end{array}$ \\
\hline $15-25$ years & $\begin{array}{c}\text { All stands in this cell have } \\
\text { been sampled }\end{array}$ & $\begin{array}{c}\text { All stands in this cell have } \\
\text { been sampled }\end{array}$ & $\begin{array}{c}\text { All stands in this cell have } \\
\text { been sampled }\end{array}$ & $\begin{array}{c}\text { All stands in this cell have } \\
\text { been sampled }\end{array}$ \\
\hline & & & & \\
\hline
\end{tabular}

Table 1. Current progress on 72 -stand matrix. $\mathrm{N}=4$ for all cells. 
Two work-study students were hired for the winter of 2008 to process samples in the lab. As of April15, all fine roots have been removed from the soil samples, and all soil samples have been processed for rocks and non-root organic matter. All tree increment cores have been mounted and sanded, and are ready for analysis.

The primary goal for the summer 2009 is to complete plot sampling for the 24 plots left unsampled the previous summer. We will also collect material accumulated in litter traps in the 48 plots sampled last year. At present, we plan to hire six crew members to work a seven-week field season during July and August to accomplish these goals. Preliminary data analysis from summer 2008 will be completed for presentation at the Ecological Society of America Annual Meeting in Albuquerque in early August.

As an effort to further develop this research and to increase the influence of my research, I worked with Dr. Jeff Hicke as he prepared a successful research proposal that was funded by NICCR for 2009. Dr. Hicke's work will extensively model beetle outbreakcarbon relationships across western North America, making use of the field measurements and superficial modeling work completed as part of my funded research. As such, Dr. Hicke and I are serving as unpaid consultants in each others' beetle outbreak research.

\section{LITERATURE CITED}

Carroll, A.L., S.W. Taylor, J. Regniere and L. Safranyik. 2004. Effects of climate change on range expansion by the mountain pine beetle in British Columbia. In: Mountain Pine Beetle Symposium: Challenges and Solutions. T., Shore, J.E. Brooks, J.E. Stone (eds.) (Natural Resources Canada, Canadian Forest Service, Pacific Forestry Centre, Kelowna, BC). pp 223-232.

Fastie, C.L., T.W. Swetnam and E.E. Berg. 1995. Annual Report of the Kenai National Wildlife Spruce Bark Beetle History Project. (U.S. Fish and Wildlife Service, Soldotna, Alaska.

Fleming, R.A. 2000. Climate change and insect disturbance regimes in Canada's boreal forests. World Resources Review 12:520-555.

Fleming, RA., J.N. Candau and R.S. McAlpine. 2002. Landscape-scale analysis of interactions between insect defoliation and forest fire in
Central Canada. Climatic Change 55:251-272.

Hicke, J.A., J.A. Logan, J. Powell and D.S. Ojima. (in press). Changing temperatures influence suitability for mountain pine beetle outbreaks in the western US. Journal of Geophysical Research-Biogeosciences.

Kashian, D.M., W.H. Romme and M. G. Ryan. In preparation. Effects of stand age and stand density on net carbon storage in lodgepole pine ecosystems. Ecological Monographs.

Kashian, D.M., W.H. Romme, D.B. Tinker, M.G. Turner and M.G. Ryan. 2006. Carbon storage on landscapes with stand-replacing fires. Bioscience 56:598-606.

Kurz, W.A. and M.J. Apps. 1999. A 70-year retrospective analysis of carbon fluxes in the Canadian forest sector. Ecological Applications 9:526-547.

Logan, J., J. Regniere and J.A. Powell. 2003. Assessing the impacts of global warming on forest pest dynamics. Frontiers in Ecology and the Environment 1:130-137.

Logan, J.A. and J.A. Powell. 2001. Ghost forests, global warming and the mountain pine beetle (Coleoptera: Scolytidae). American Entomologist 47:160-173.

Romme, W.H., D.H. Knight and J.B. Yavitt. 1986. Mountain pine beetle outbreaks in the Rocky Mountains regulators of primary productivity. American Naturalist 127:484-494.

Samman, S. and J.A. Logan. 2000. Assessment and response to bark beetle outbreaks in the Rocky Mountain area: report to Congress from Forest Health Protection Washington Office Forest Service. U.S. Department of Agriculture Gen. Tech. Rep. RMRS-GTR-62, USDA Forest Service, Rocky Mountain Research Station, Ogden, UT.

USDA Forest Service. 2005. Forest Insect and Disease Conditions in the United States, 2004. Washington, D.C.

Williams, D.W. and A.M. Liebhold. 2002. Climate change and the outbreak ranges of two North American bark beetles. Agricultural and Forest Entomology 4:87-99. 